\title{
METODE 2D HYBRID ANIMATION DALAM PEMBUATAN FILM ANIMASI DI MACROMEDIA FLASH MX
}

\author{
Jacky Sukmana \\ Lembaga Pengembangan Teknologi Informasi dan Komunikasi, Universitas Bengkulu. \\ Jl. W.R. Supratman Kandang Limun Bengkulu 38371 A Sumatera-INDONESIA \\ (telp: +62 73621170 ; fax: +62 736 22105) \\ sukmanajacky@gmail.com
}

\begin{abstract}
Abstrak: Industri film kartun di Indonesia saat ini masih jauh dari yang diharapkan, dimana film kartun pada stasiun Televisi Indonesia masih mengimpor dari negara lain, khusunya pada Negara Jepang dan Amerika Serikat. Hal ini berkaitan dengan besarnya investasi dan rutinitas sumber daya manusia (SDM) yang ada. Para animator Indonesia beranggapan bahwa industri film kartun membutuhkan biaya yang besar serta sumber daya manusia yang benar-benar menguasai dan memahami seluk beluk pembuatan kartun yang dinilai rumit. Namun dengan system komputerisasi sekarang ini, kita dapat memproduksi film kartun animasi dengan murah dan cepat. Ada beberapa pilihan dalam teknik pembuatan film animasi ini, seperti contoh system operasi Machintos serta aplikasi 3D Studio Max yang berjalan pada system operasi Windows, tetapi pengoperasian teknologi tersebut tergolong mahal dan harus mempunyai keterampilan yang khusus. Penulis mengenalkan teknologi Macromedia Flash yang memiliki kemampuan antara lain, flash merupakan suatu program grafis dengan system vector, waktu loading baik untuk animasi film ataupun game, dan ditunjang dengan beberapa action Scrip penting dapat kita manfaatkan dan mampu mengerjakan sejumlah frame dengan urutan. Membuat animasi dengan cara menggambar manual di kertas, di scan dan di transfer pada computer untuk dapat merubahnya menjadi image digital. Disebut hybrid, karena menggabungkan kemampuan gambar manual di kertas dengan penggunaan aplikasi terkomputerisasi. Apalagi didukung oleh sumber daya manusia yang produktif dan memiliki kreatifitas tinggi, sehingga mampu menghasilkan produk yang bernilai positif bagi perkembangan dunia kartun dan animasi di Indonesia.
\end{abstract}

Kata Kunci: 2D Hybrid, Metode Hybrid, Animasi film, Pembuatan film animasi

Abstract: The cartoon industry in Indonesia is currently far from being expected, where cartoons at Indonesian Television stations still import from other countries, especially in Japan and the United States. This is related to the amount of investment and routine human resources (HR) available. The animators of Indonesia assume that the cartoon film industry requires a large cost and human resources who really master and understand the ins and outs of making a complicated cartoon. But with today's computerized system, we can produce animated cartoon movies cheaply and quickly. There are several options in this animated film making techniques, such as the example of Machintos operating system and 3D Studio Max applications running on Windows operating system, but the operation of such technology is expensive and must have special skills. The author introduces Macromedia Flash technology that has the ability, among others, flash is a graphics program with the system vector, loading time for both animated movies or games, and supported by some important Script action we can use and be able to work on a number of frames in sequence. Creating animation by drawing manually on paper, scanned and transferred to computer to convert it into digital image. Called hybrid, because it combines the capabilities of manual drawing on paper with the use of computerized applications. Moreover, supported by productive human resources and have high creativity, so as to produce a positive product for the development of the world of cartoons and animation in Indonesia.

Keywords: 2D Hybrid, Hybrid Method, Animation Film, The Process of Animation Film 


\section{PENDAHULUAN}

Stasiun televisi dewasa ini menayangkan film kartun yang disenangi oleh banyak pemirsa, tidak hanya oleh anak-anak, tetapi juga oleh orang dewasa. Karena film kartun dapat menampung segala daya imajinasi manusia. Pada hakekatnya manusia ingin selalu bebas berekspresi dan tidak mau di batasi oleh apapun seperti yang di temui pada kehidupan sehari-harinya. Industri film kartun di Indonesia sendiri saat ini masih jauh dari yang di harapkan, dimana film kartun pada Stasiun Televisi Indonesia masih mengimpor dari negara lain, khususnya pada negara Jepang dan Amerika Serikat. Hal ini berkaitan dengan besarnya investasi dan rutinitas Sumber Daya Manusia (SDM) yang ada.

Jepang sebagai peringkat terbesar, memimpin di inovasi, kreatifitas untuk digital Content Produk, leading berturut-turut di skill animasi, games, effect, quality of work force attitude, teknik dan kualitas produksi, pemasaran global dan promosi, perlindungan hak cipta (copy right) dan bandwith, akses Internet. Indonesia berada pada posisi terendah jauh di bawah Industri animasi di Jepang dan Korea yang sudah maju pesat. Para Animator Indonesia beranggapan bahwa industri film kartun membutuhkan biaya yang besar serta sumber daya manusia yang benarbenar menguasai dan memahami seluk beluk pembuatan kartun yang di nilai rumit. Mereka juga menilai industri film kartun ini memiliki prospek ke depan yang kurang menjanjikan, padahal Negara Jepang sendiri mendapatkan keuntungan yang besar dari mengekspor film kartun animasi buatan mereka.

Namun dengan sistem komputerisasi sekarang ini, kita dapat memproduksi film kartun animasi dengan murah dan cepat. Ada banyak pilihan dalam teknologi pembuatan film animasi ini, seperti contoh sistem operasi Machintos serta aplikasi 3D Studio Max yang berjalan pada windows. Pengoperasian teknologi tersebut tergolong mahal dan harus mempunyai keterampilan yang khusus. Penulis mengenalkan teknik produksi 2D Hybrid Animation dikarenakan peralatan yang cukup meunjang untuk berproduksi, penguasaaan materi dan ketertarikan pada penggabungan antara manual skill dan digital skill. Yang akan di kombinasikan menggunakan aplikasi Macromedia flash yang memiliki kemampuan antara lain, flash merupakan suatu program grafis dengan system vector. Waktu loading baik untuk animasi film ataupun game, sangat cepat lebih cepat dari program sejenis lainnya, kemampuannya sebagai program pembuat web interaktif dan film animasi, karena ditunjang beberapa action script penting dapat kita manfaatkan untuk membuat game. Mampu menganimasikan grafis, sekaligus dalam ukuran besar, dengan cepat dan mampu mengerjakan sejumlah frame dengan urutan. Apalagi jika didukung oleh Sumber Daya Manusia yang produktif dan memiliki kreatifitas tinggi sehingga mampu menghasilkan produk yang bernilai positif bagi perkembangan dunia kartun dan animasi di Indonesia.

Berdasarkan dari uraian di atas, maka penulis tertarik dengan judul Metode 2D Hybrid Animaton dalam Pembuatan Film Animasi di Macromedia Flash Mx.

\section{LANDASAN TEORI}

\section{A. Bentuk Animasi}

Sedangkan dalam multimedia ada 9 macam animasi yaitu penggunaaan computer untuk menciptakan gerakan pada layer. 
1. Animasi Sel (Cell Animation).

Kata 'cell' berasal dari 'celluloid' yang merupakan material yang di gunakan untuk membuat film bergerak pada saat animasi awal. Sekarang material film di buat dari asetat (acetate) bukan celluloid. Animasi di buat pada potongan asetat atau sel (cell). Sel animasi merupakan sel yang terpisah dari frame animasi tunggal. Sel animasi aktif terpisah dari lembaran latar belakang dan sebuah sel untuk masing-masing objek yang bergerak secara mandiri di atas latar belakang. Lembaran ini memungkinkan seorang animator untuk memisahkan dan menggambar kembali gambar-gambar yang berubah antara frame beruntun. Sebuah frame terdiri dari sel aktif dan sel background.

\section{Animasi Frame (Frame Animation).}

Animasi Frame adalah bentuk animasi yang mempunyai gambar berseri di tepi halaman berurutan. Jika jempol anda membuka buku dengan cepat, maka gambar akan kelihatan bergerak. Pada komputer multimedia, animasi buku tersebut menampilkan sebuah gambar yang berurutan secara cepat. Antara gambar satu (frame satu) dengan gambar yang lain (frame lain) berbeda. Dalam sebuah film, serangkaian frame bergerak melalui proyektor film dengan kecepatan 24 fps.

\section{Animasi Sprite (Sprite Animation).}

Animasi Sprite serupa dengan animasi tradisional, yaitu objek yang di letakkan di animasikan pada bagian puncak grafik dengan latar belakang diam. Sprite adalah setiap bagian dari animasi yang bergerak secara mandiri, misalnya burung terbang, planet berotasi, bola memantul, logo berputar dan sebagainya. Sprite beranimasi dan bergerak sebagai objek mandiri.

\section{Animasi Lintasan (Path Animation).}

Animasi lintasan adalah animasi dari objek yang bergerak sepanjang garis kurva yang telah di tentukan sebagai lintasan.

5. Animasi Spline (Spline Animation).

Spline adalah representasi matematis dari kurva. Objek bergerak biasanya tidak mengikuti garis lurus, misalnya bentuk kurva, program animasi komputer memungkinkan untuk membuat animasi spline dengan lintasan gerak berbentuk kurva.

6. Animasi Vektor (Vecktor Animation).

Animasi vektor serupa dengan animasi sprite. Animasi sprite menggunakan bitmap untuk sprite. Animasi vektor menjadikan objek bergerak dengan memfariasikan ketiga parameter ujung pangkal, arah, dan panjang pada segmen-segmen garis yang menentukan objek.

7. Animasi Karakter (Character Animation). Animasi karakter merupakan sebuah cabang khusus animasi. Animasi karakter dapat di lihat dalam film kartun. Animasi ini berbeda dengan animasi lainnya, misalnya animasi logo yang melibatkan bentuk on organik dengan penggandan yang banyak. Animasi karakter menghasilkan gerakan yang hierarkis. Tidak hanya mulut, mata, muka dan tangan yang bergerak, tetapi semua gerakan seorang tokoh pada waktu yang sama.

\section{Computational Animation.}

Animasi ini membutuhkan waktu singkat tanpa membuat boros memori komputer. Dengan computational animation, untuk menggerakkan objek di layar cukup dengan memvariasikan koordinat $\mathrm{x}$ dan $\mathrm{y}$, $\mathrm{x}$ merupakan posisi horizontal objek, yaitu kanan dan kiri layar. Sedangkan 
koordinat y mewakili posisi vertikal objek, yakni atas dan bawah layar.

\section{Morping.}

Kadang kala kita menemui sebuah animasi yang dapat berubah dari satu bentuk yang lain dengan menampilkan serangkaian frame yang begitu halus saat bentuk pertama mengubah dirinya menjadi bentuk yang lain.

\section{B. Teknik Produksi Animasi 2D}

Animasi secara sederhana di artikan dengan menggerakan suatu benda mati secara berurutan (sequence) seolah-olah menjadi hidup. Dari pengertian yang sederhana inilah akan muncul karya yang luar biasa bila di gabungkan dengan skill video editing, skill menggambar animasi dan imajinasi sebagai pengembang daya ciptanya. Berikut ini adalah rincian teknik produksi film animasi.

\section{* 2D Hybrid Animation}

Membuat animasi dengan cara menggambar manual di kertas, di scan dan di transfer ke komputer untuk dapat merubahnya menjadi image digital. Di sebut hybrid, karena menggabungkan kemampuan gambar manual di kertas dengan penggunaan aplikasi terkomputerisasi.

Peralatan yang di gunakan dalam $2 D$ hybrid animation adalah :

1. komputer sebagai tempat proses pewarnaan yang tak pernah habis dan mudah dalam mengindeks warna. Sebagai tempat proses menggerakkan gambar animasi, proses editing, pengisian suara dan lain sebagainya.

2. $2 D$ Scanner sebagai pengganti video/ movie camera.

3. Light Tracing Table, meja beralas kaca tembus pandang, terdapat lampu di bawahnya guna melihat gambar yang telah di buat sebelumnya.
4. Kertas biasa seukuran area Scan, dengan perbandingan 4 dan tinggi 3 biasanya di sebut dengan nama Ratio 4:3, ukuran pastinya dapat di sesuaikan selama masih muat di area scaner.

5. Video Capture card, bila ingin menggabungkan/ Compositing Video hasil shooting dengan animasi.

6. Sound Card, guna merekam suara.

7. CD RW atau DVD RW untuk mentransfer ke dalam format VCD atau DVD.

\section{Tahapan dalam Memperoses Animasi}

Riset dan pengumpulan data seperti menentukan tema cerita, sinopsis dan skrip, memunculkan karakter sifat dan ciri, pengumpulan dokumentasi, peta lokasi, hal ini diasumsikan sudah ada, atas dasar itu maka tahapan proses produksi film animasi dapat disusun sebagai berikut:

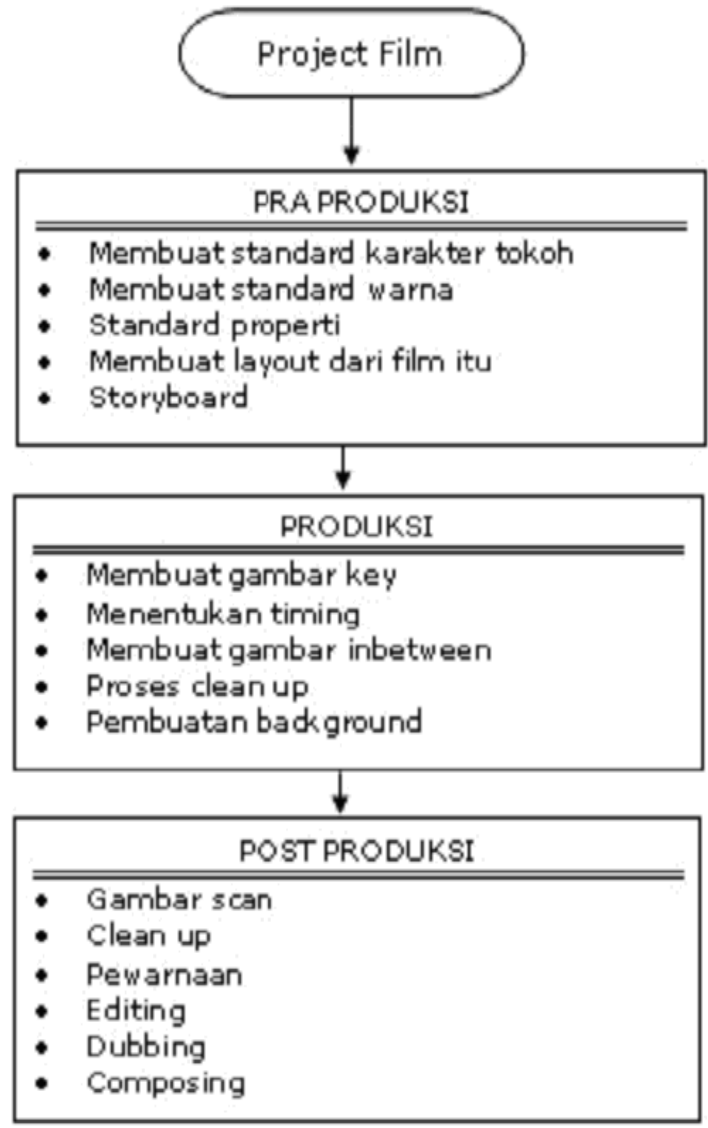

Gambar 1. Tahapan dalam pembuatan sebuah film 
Berdasarkan diagram di atas, terdapat tahapan dalam memproduksi film animasi. Tahapan tersebut harus di lakukan secara sistematis karena tiap-tiap elemennya memiliki keterkaitan dalam hal kinerja yang bersifat kontinuitas. Pembahasan masing-masing tahapan akan di jelaskan pada bab berikutnya.

\section{Macromedia Flash}

Flash merupakan program grafis multimedia dan animasi yang dapat dipergunakan untuk membuat aplikasi web interaktif yang menarik. Namun demikian bahasan ini tidak menutup kemungkinan untuk diaplikasikan pada macromedia Flash MX atau flash 8.0.

\section{METODOLOGI}

Langkah-langkah yang dilakukan dalam penelitian ini adalah:

\section{1) Pra Produksi}

Meliputi perancangan karakter, penulisan naskah, skenario, dan pembuatan storyboard.

2) Desain Karakter (Character Design)

Karakter adalah kepribadian, setiap karakter tersebut biasanya mempunyai kekuatan, kelemahan, kelakuan, dan kebiasaan yang khas. Bertujuan mendefinisikan apa yang mereka lakukan, mengapa mereka melakukan, dan bagaimana mereka melakukannya. Nabi Musa AS adalah contoh pendefinisian karakter yang sangat bagus, menggambarkan seorang yang tinggi, agak kurus, berusia kira-kira berumur 44-45 tahun. Memiliki kepandaian yang sangat tinggi, sangat terobsesi dan biasa mengatur emosi. Memakai kostum panjang, membawa tongkat, dia seorang rasul utusan Allah Swt.

3) Naskah (Storyline)

Naskah dapat di buat dengan gaya bahasa dan penulisan layaknya sebuah novel. Pemaparan cerita di buat lebih jelas dan detail tentang keadaan lingkungan dalam cerita, hingga ekspresi, dan perasaan sang karakter. Naskah memegang peranan penting dalam menentukan durasi sebuah film. Namun sepenuhnya kelak tergantung pada sang Sutradara seberapa lama sebuah adegan/ cut di ambil. Melalui pendramatisiran, tiap adegan yang di sertai musik latar dapat pula di gambarkan dengan diagram scene seperti di bawah ini.

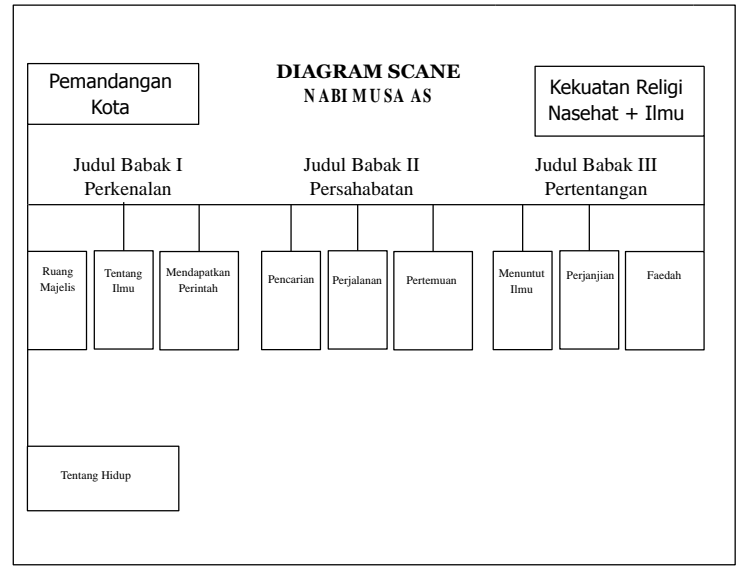

Gambar 2. Diagram Scene

4) Skenario (Script)

Penulisan Skenario di kerjakan oleh seorang Script Writer, di tulis dengan gaya penulisan yang berbeda dengan naskah. Skenario berguna dalam memastikan pengambilan adegan, aksi tokoh, dialog antar tokoh-tokohnya, hingga suara- suara yang di inginkan dalam film, baik suara berupa efek, maupun berupa musik ilustrasi.

5) Teknik Pengambilan Gambar

Dalam Film nyata, pengambilan gambar dapat di ambil dengan mudah oleh kameramen dengan menggunakan kamera video. Sutradara dapat mengambil posisi dan sudut pandang tiap adegan tanpa kesulitan berarti. Sedangkan dalam Film Kartun, pengambilan gambar di rencanakan dengan menggunakan imajinasi terlebih dahulu, membayangkan sudut pandang yang pas dan enak di lihat, bekerjasama dengan sutradara, selanjutnya akan di visualisasikan oleh Storyboard artis untuk menggambarkannya. 
Jurnal Pseudocode, Volume V Nomor 1, Februari 2018, ISSN 2355-5920 www.ejournal.unib.ac.id/index.php/pseudocode

\begin{tabular}{|c|c|}
\hline \multicolumn{2}{|r|}{ Tabel 1. Istilah Kamera } \\
\hline ISTILAH & KETERANGAN \\
\hline Distance Shot & $\begin{array}{l}\text { Pengambilan jarak jauh untuk } \\
\text { menangkap action dalam kelompok } \\
\text { besar. Umpamanya adegan } \\
\text { pertempuran, iringan pasukan } \\
\text { berkuda atau konvoi. }\end{array}$ \\
\hline Camera Angle & $\begin{array}{l}\text { Sudut pandang kamera menangkap } \\
\text { subjek }\end{array}$ \\
\hline High Angle & $\begin{array}{l}\text { Kamera menangkap subjek yang } \\
\text { berada di bawah }\end{array}$ \\
\hline Low Angle & $\begin{array}{l}\text { Kamera menangkap subjek yang } \\
\text { berada di atas }\end{array}$ \\
\hline Close Shot & Jarak pengambilan dekat \\
\hline $\begin{array}{l}\text { Close } \quad U p \\
(C U)\end{array}$ & $\begin{array}{l}\text { Shot penekanan yang mengundang } \\
\text { perhatian pada suatu aspek dari } \\
\text { subjek, dalam kaitanya dengan } \\
\text { subjek manusia, shot mengenai } \\
\text { wajah saja atau kaki saja }\end{array}$ \\
\hline Off Shot $(O S)$ & $\begin{array}{lll}\text { Tidak tampak gambar tapi } \\
\text { suaranya terdengar }\end{array}$ \\
\hline $\begin{array}{ll}\text { Long } & \text { Shot } \\
(L S) & \end{array}$ & Shot yang subjeknya jauh \\
\hline $\begin{array}{l}\text { Medium Shot } \\
(M S)\end{array}$ & $\begin{array}{l}\text { Shot yang diambil lebih dekat pada } \\
\text { subjeknya dibandingkan long shot, } \\
\text { tapi tidak lebih dekat dengan close } \\
\text { up. Dalam kaitanya dengan } \\
\text { manusia, shot yang menampilkan } \\
\text { tubuh manusia kurang lebih dari } \\
\text { pinggang ke atas. }\end{array}$ \\
\hline $\begin{array}{l}\text { Medium Close } \\
U p(M C U)\end{array}$ & $\begin{array}{l}\text { Orang yang ditangkap dalam jarak } \\
\text { ini akan terlihat dari batas siku dan } \\
\text { beberapa inci di atas kepalanya. }\end{array}$ \\
\hline Slow Motion & $\begin{array}{l}\text { Gambar yang terjadi di sebuah shot } \\
\text { yang disuguhkan lebih lambat } \\
\text { daripada gerakan yang sebenarnya. } \\
\text { Lawanya adalah Accelerated } \\
\text { Motion }\end{array}$ \\
\hline Two Shot & $\begin{array}{l}\text { Shot yang menampilkan dua orang, } \\
\text { biasanya dari pinggang ke atas }\end{array}$ \\
\hline Fide In & $\begin{array}{l}\text { Awal sebuah shot yang beranjak } \\
\text { dari kegelapan dan berangsur- } \\
\text { angsur menjadi teranghingga } \\
\text { cemerlang sesungguhnya }\end{array}$ \\
\hline Fide Out & Lawan dari fide In \\
\hline
\end{tabular}

\section{6) Storyboard}

Storyboard adalah sketsa Film dalam bentuk gambar berurutan. Storyboard di buat oleh seorang Storyboard Artist sebelum masuk ke penggambaran gerak karakter dan animasi film berdasarkan script (skenario). Kegunaan Storyboard adalah sebagai dasar rancangan gerak objek pada Film. Menggambar Storyboard umumnya di lakukan pada lembaran kertas. Dalam Film atau video shooting, untuk mengerti suatu adegan, Sutradara terkadang cukup membaca dari script. Tetapi dalam membuat animasi, script ini harus di terjemahkan lagi lebih lanjut ke dalam format Storyboard. Namun, bila naskah yang di buat berdasarkan buku komik atau dalam bahasa jepang di sebut 'Manga', maka komik tersebut bisa di jadikan Storyboard karena bentuk komik sudah mirip Storyboard. komik bukan Storyboard. Sebab, Storyboard sesungguhnya hanya berupa gambar, tanpa balon suara. Lalu di Storyboard semua keterangan berupa siapa yang berdialog, bagaimana suasananya, dari mana arah cahaya datang dan semua informasi yang di perlukan di tulis di bawahnya, mirip cerpen.
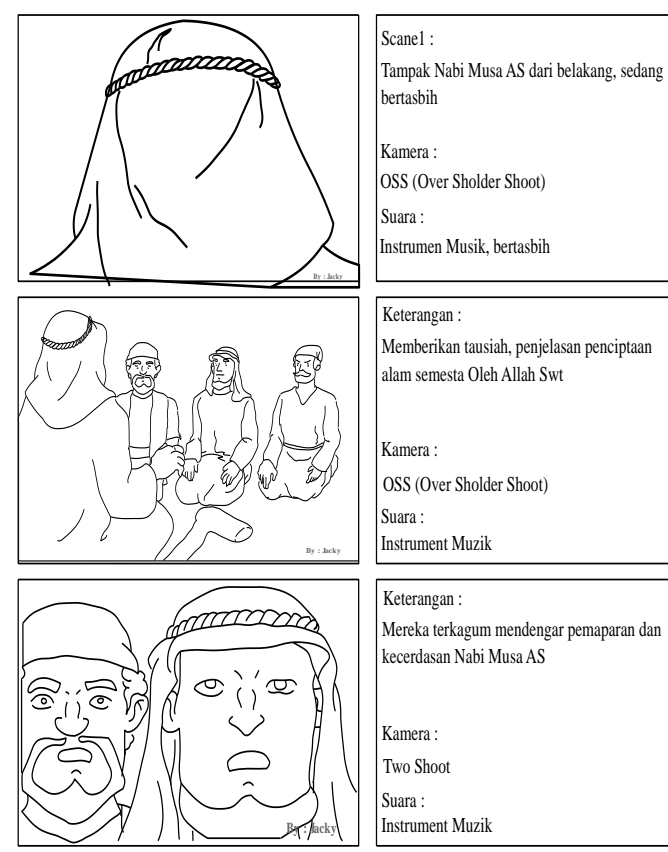

Keterangan :

Mereka terkagum mendengar pemaparan dan kecerdasan Nabi Musa AS

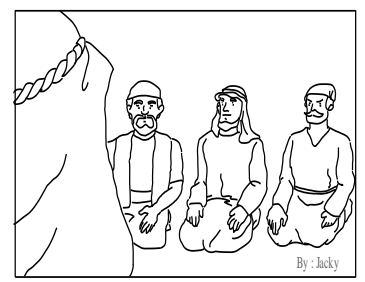

Instrument Muzik

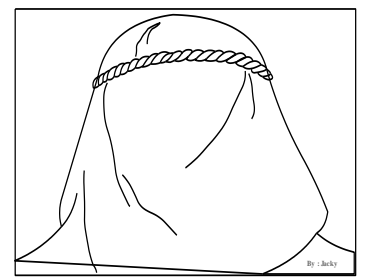

Keterangan :

Dengan semangatnya, para sahabat mendengarkan tausiah Nabi Musa AS

Kamera :

OSS (Over Sholder Shoot)

Suara :

Instrument Muzik

Gambar 3. Contoh Storybord dengan Script 


\section{HASIL DAN PENELITIAN}

\section{A. Pembahasan dalam Tahap Produksi}

Inti dari proses pembuatan film kartun adalah pada tahap produksi. Dalam tahap ini terjadi beberapa pekerjaan yang di lakukan secara estafet dan teratur. Di mulai dari Animator, colorist, hingga editor. Karena film animasi Nabi Musa AS. ini di buat dengan teknik produksi $2 D$ Hybrid Animation, maka ada beberapa bagian yang di kerjakan secara manual tanpa menggunakan perangkat digital.

\section{B. Drawing}

Gambar-gambar yang akan di animasikan di buat oleh animator dengan cara di gambar manual di atas kertas dengan menggunakan light table tracing (meja tracing). Sebuah meja yang di bawahnya terdapat lampu guna memberikan penerangan pada saat menggambar animasi. Dengan berpedoman pada storyboard yang di buat oleh storyboard artis, animator bekerja membuat gambar-gambar yang seolah hidup ketika di animasikan. Contoh gambar burung dibawah ini.

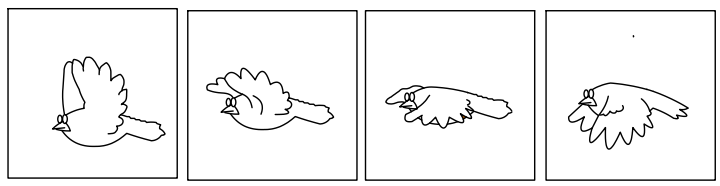

Gambar 4. Rentetan gambar burung terbang

C. Menggambar Latar Belakang dan Objek

1. Sebuah animasi tidak akan bagus jika tidak diberi lingkungan. Lingkungan inilah Yang memberi kesan animasi menjadi hidup.

2. Menggambar latar belakang harus sesuai dengan jalan cerita yang sudah ditentukan sebelumnya dalam storyboard.

3. Agar gerak tidak terlalu monoton. Gunakan imajinasi untuk menggambar background dalam berbagai sudut pandang.
4. Untuk membuat background 3D kita bisa menggunakan bantuan 3dsmax, namun yang lebih mudah adalah Swift3D, karena lebih simple dan hasilnya dapat langsung diekspor dalam format shockwave flash (swf).

\section{Pewarnaan}

Dengan penguasaan teori warna yang baik maka kita bisa untuk mewarnai objek kita, bisa memadukan beberapa warna yang serasi. Pewarnaan juga akan lebih optimal jika memperhatikan teknik pencahayaan (gelap-terang) sehingga warna objek lebih menarik.

\section{E. Proses Animasi}

Untuk melakukan animasi, kuasai dulu teknik penganimasian di Flash:

1. Animasi gerak, posisi, $\diamond$ Tween Motion \& rotasi objek

2. Animasi modifikasi/perubahan bentuk objek $\diamond$ Tween Shape

3. Animasi dilakukan per karakter, per objek, dan latar belakang sesuai dengan jalan cerita.

4. Untuk memudahkan, sebaiknya semua objek kita satukan terlebih dahulu.

5. Agar lebih mudah animasi sebaiknya dilakukan per karakter langsung karena kita menggunakan metode hybrid.

\section{F. Hasil Produksi Dalam Tahapan Pasca Produksi}

Akhir dari proses pembuatan film kartun adalah pada tahap pasca produksi. Dalam tahap ini terjadi beberapa pekerjaan yang di lakukan secara estafet dan teratur. Di mulai dari Pengisian suara sampai konversi animasi flash (SWF) ke VCD.

\section{KESIMPULAN}

Setelah penulis menyelesaikan hasil penelitian, maka dapat di ambil beberapa kesimpulan, yaitu: 
a. Ada 3 macam cara dalam memproduksi film kartun :

1. 2D Stop Motion Animation, men-shoot gambar satu persatu (frame by frame), contohnya film kartun klasik dan clay animation (animasi tanah liat).

2. 2D Hybrid Animation, membuat film kartun dengan gambar tangan untuk selanjutnya di kerjakan secara digital di komputer.

3. 2D Digital Animation, yaitu pembuatan film kartun dengan peralatan serba digital dan terkomputerisasi.

b. Pada proses pembuatan sebuah film animasi, ada 3 tahapan besar yang harus di lakukan, yaitu :

1. Pra Produksi, yang meliputi, ide, perancangan karakter, penulisan naskah, skenario, dan pembuatan storyboard.

2. Produksi, yang meliputi pembuatan key, animasi In Between, perancangan background dan foreground, pewarnaan digital, editing, serta pemberian efek visual.
3. Pasca Produksi, terdiri dari dubbing Voice, pemberian sound efek, backsound, sinkronisasi antara gerakan dan visual dengan audio, hingga finishing berupa rendering dan konversi ke VCD.

c. Penyesuaian Background musik dan sinkronisasi antara gerakan visual dan dubbing yang pas menghasilkan animasi yang bagus dan enak di tonton.

\section{REFERENSI}

[1] Abeng.2008.Membuat Film Kartun dengan Flash MX.Elex Media.PDF

[2] Gregorius. 2009. Teknik Menggambar Kartun dengan Flash.Elex Media.174 Halaman

[3] Hendi\&Roby 2008. The Magic Of 3DS Max.Informatika Bandung.428 Halaman

[4] http://mabenihanoi.wordpress.com/2008/04/22/membuat -film-animasi-2d-dengan- macromedia-flash/

[5] Sudirman.2009. 10 Animasi Kartun Flash. Maxicom.192 Halaman 